\title{
Staining of Tissues With Dye Extracts of Pterocarpus osun: Choice of a Fixative
}

\author{
Tinción de Tejidos con Extractos de Pterocarpus osun: Opción de un Fijador
}

"Avwioro, O. G.; **Aloamaka, P. C. \& ***Imosemi, I. I.

AVWIORO, O. G.; ALOAMAKA, P. C. \& IMOSEMI, I. I. Staining of tissues with dye extracts of Pterocarpus osun: The choicce of a fixative. Int. J. Morphol., 23(4):397-398, 2005.

SUMMARY: The effect of the fixatives: 10\% formol saline, Carnoy's fluid, Zenker's fluid, Helly's fluid and Bouin's fluid on the staining ability of the extracts of Pterocarpus osun (P. osun) on tissue sections was studied. Tissues were fixed in the fixatives, processed by the paraffin wax method and the sections were stained with alcoholic extract of P. osun in acidic, neutral and alkaline media. No significant difference was observed in the staining reactions.

KEY WORDS: Histological technique; Stainning of tissues; Peterocarpus osun.

\section{INTRODUCTION}

The study was done in order to determine the most appropriate fixative for staining of sections with the extract of Pterocarpus osun. P. osun. is a forest tree that belongs to the family of Papillionaceae (Keay 1989). Its staining potentials for collagen fibres, muscles and red blood cells had previously been described by Avwioro et al. (2005). Sometimes the choice of a fixative for tissues influences subsequent histochemical reactions (Culling, 1974). This is because fixatives are chemicals and they react with tissue structures to produce new compounds, which are capable of withstanding autolysis and putrefaction. Generally, tissues, which contain acetic acid, favour the staining of cytoplasm (Avwioro, 2002). Formalin a major constituent of $10 \%$ formol saline supports many staining techniques, Carnoy's fluid, which contains alcohol and acetic acid, is a good fixative for chromosome studies. Zenker's fluid is good for the trichrome methods for collagen fibres while Helly's fluid is said to be a good fixative for micro-anatomical and cytological studies (Avwioro).

\section{MATERAL AND METHOD}

Tissues were fixed in $10 \%$ formol saline, Carnoy's fluid, Zenker's fluid, Helly's fluid, and Bouin's fluid, for 24 hours and processed for paraffin wax embedding. Sections were cut at $4 \mathrm{~mm}$ with the Rotary microtome and stained with Weigert's haematoxylin, differentiated in $1 \%$ acid alcohol and blued in tap water. The sections were subsequently stained with various alcoholic dilutions of the dye in acidic, alkaline and neutral media, with the use of $1 \%$ acetic acid, potassium ammonium alum and ethanol, respectively. Tissues were stained for 10 minutes, at room temperature, dehydrated, cleared and mounted in a synthetic medium.

\section{RESULTS AND DISCUSSION}

There was no significant difference in the staining reactions of the various dilutions of the stain in tissue sections fixed in $10 \%$ formol saline, Carnoy's fluid, Zenker's fluid Helly's fluid and Bouin's fluid. The staining time, intensity and the ability to withstand the bleaching effect of the dehydrating alcohol were compared with those of the tissues fixed in $10 \%$ formol saline. The experiment was performed on normal and post mortem tissues from intestine, skin, kidney, heart, liver and spleen so that a reasonable number of tissue structures would be investigated. Culling had observed that the choice of a fixative affects histochemical reactions. This has not been so with the fixatives studied with dye extracts from $P$. osun. It was therefore concluded that any of the aforementioned fixatives could be used when the extracts of $P$. osun are to be used for histology.

* School of Medical Laboratory Science, Obafemi Awolowo University Teaching Hospital, Ile Ife, Nigeria.

** Department of Physiology, Ambrose Alli University, Ekpoma, Nigeria.

*** Department of Anatomy, University of Ibadan, Nigeria. 
AVWIORO, O. G.; ALOAMAKA, P. C. \& IMOSEMI, I. I. Tinción de tejidos con extractos de Pterocarpus osun: Opción de un fijador. Int. J. Morphol., 23(4):397-398, 2005.

RESUMEN: En secciones de tejidos fueron estudiados los efectos de los fijadores: formalina al 10\% y líquidos de Carnoy, de Zenker, de Helly y de Bouin en la capacidad de tinción con Pterocarpus osun. Los tejidos fueron colocados en los fijadores, procesados en parafina y las secciones fueron teñidas con extracto alcohólico Pterocarpus osun, en medios ácido, neutro y alcalino. No fueron observadas diferencias en las tinciones.

PALABRAS CLAVE: Técnica histológica; Tinción de tejidos; Pterocarpus osun.

\section{REFERENCES}

Avwioro, O. G.; Aloamaka, P. C.; Ojianya, N. U.; Oduola, T. \& Ekpo, E. O. Extracts of Pterocarpus osun as a histological stain fore collagen fibres. African $J$. biotechnology, 5:460-2, 2005.

Avwioro, O. G. Histochemistry and tissue pathology 1. St. Claverianum press, Ibadan, 2002. pp 134-213.

Culling, C. F. A. Handbook of histochemical histopathological techniques 3. ed. Butterworth, London, 1974. pp 29-61.

Keay, R. W. J. Trees of Nigeria. Oxford science publications, 85-8, 1989.
Correspondence to: Dr. Godwin Avwioro School of Medical Laboratory Science Obafemi Awolowo University Teaching Hospital, Ile Ife, Nigeria

Tel: 2348037149777

Email:avwiorog@yahoo.com

Received: 01-09-2005

Accepted : 04-10-2005 